\title{
Penerapan Pembelajaran Tematik Melalui Model Kooperatif Think Pair Share (TPS) Untuk Meningkatkan Hasil Belajar Siswa Kelas III SDN 12 Bengkulu Tengah
}

\section{Weni Rosalina}

Program Magister Pendidikan Dasar Universitas Bengkulu. rosalukman89@gmail.com

\section{Daimun Hambali}

Program Magister Pendidikan Dasar Universitas Bengkulu.

\author{
Abdul Muktadir \\ Program Magister Pendidikan Dasar Universitas Bengkulu.
}

\section{Abstract}

Pembelajaran tematik dengan menggunakan model kooperatif TPS bertujuan untuk meningkatkan hasil belajar siswa dalam aspek afektif/ sikap, kognitif/ pengetahuan, dan psikomotor/ keterampilan. Metode penelitian ini adalah penelitian tindakan kelas (PTK) yang dilaksanakan dalam 3 siklus yang terdiri dari tahapan ditiap siklusnya yaitu perencanaan, pelaksanaan, pengamatan dan refleksi. Penelitian ini dilakukan di kelas III SDN 12 Bengkulu Tengah data yang diperoleh melalui pengamatan pada guru dan siswa untuk mengetahuai aktivitas proses pembelajaran dan tes hasil belajar. Data dianalisis menggunakan nilai rata-rata, persentase ketuntasan belajar, kemuian dikategorikan. Hasil penelitian menunjukkan proses pembelajaran dan hasil belajar siswa meningkat. Hasil belajar siswa pada LKPD siklus 1 memperoleh nilai rata-rata 66,66, meningkat pada siklus 2 menjadi 72,5, dan meningkat kembali pada siklus 3 78,87, nilai evaluasi pada akhir pembelajaran pada siklus 1 memperoleh nilai rata-rata 71,25, meningkat pada siklus 2 menjadi 75, dan meningkat kembali pada sisklus 3 menjadi 78,33, nilai afektif/ sikap pada sisklus 1 memperoleh persentase cukup dengan interval tiap aspek (1,7-2,30, meningkat pada siklus 2 dengan persentase baik dengan interval tiap aspek (2,4-3), menjadi lebih baik lagi pada siklus 3, nilai psikomotor/ keterampilan pada siklus 1 memperoleh persentase cukup dengan interval tiap aspek (1,7-2,3), meningkat pada siklus 2 dengan persentase menjadi baik dengan interval tiap aspek (2,4-3), dan pada siklus 3 menjadi lebih baik lagi. Hal ini menunjukakan bahwa dengan penerapan pembelajaran tematik melalui model kooperatif TPS pada kelas III SDN 12 Bengkulu tengah dapat meningkatkan hasil belajar siswa.

Kata kunci : Pembelajaran Tematik, Model Kooperatif TPS, dan hasil belajar 


\section{Pendahuluan}

Pendidikan merupakan faktor penting dalam pembangunan suatu bangsa. Kualitas suatu sistem pendidikan dapat mempengaruhi kualitas suatu bangsa di masa depan. Ketika suatu bangsa mengalami keterpurukan dan diperparah dengan kualitas sumber daya manusia yang rendah lazimnya sering dikaitkan dengan lemahnya peran pendidikan dalam membentuk manusia yang unggul. Saat ini sudah semakin disadari bahwa pendidikan sangat penting didalam kehidupan sosial.

Pendidikan adalah usaha sadar dan terencana untuk mewujudkan suasana belajar dan proses pembelajaran agar peserta didik secara aktif mengembangkan potensi dirinya untuk memiliki kekuatan spiritual keagamaan, pengendalian diri, kepribadian, kecerdasan, akhlak mulia, serta keterampilan yang diperlukan dirinya, masyarakat, bangsa dan negara, Depdiknas (2003: 5). Menurut Seda (1970) (dalam Kunandar 2007: 10) bahwa pendidikan harus mampu berfungsi mengubah sikap yang kolot dan mampu menggalakkan inovasi dan mempengaruhi secara kreatif pola dan perilaku masyarakat.

Seorang guru memegang peranan penting di dalam proses interaksi pembelajaran karena bagaimana juga keadaan sistem pendidikan di Sekolah Dasar (SD), alat yang digunakan dan keadaan siswa pada akhirnya bergantung kepada guru dalam mengelola komponen yang ada. Metode dan keputusan guru di dalam interaksi pembelajaran sangat menentukan keberhasilan siswa untuk mencapai tujuan pembelajaran. Sebagai pemegang peranan yang sangat penting, guru dituntut untuk menguasai berbagai metode dan pendekatan mengajar serta terampil dalam menggunakan alat peraga. Dengan kata lain kualitas pembelajaran tergantung kepada kemampuan guru dalam memadukan secara sistematis dan sinergis guru, kurikulum, bahan belajar, media, fasilitas, sistem, pembelajaran dalam menghasilkan proses dan hasil belajar yang optimal sesuai dengan tuntutan kurikulum.

Kurikulum 2013 ditekankan adanya peningkatan dan keseimbangan pada aspek sikap, keterampilan, dan pengetahuan. Jika selama ini, penilaian hanya menekankan pada aspek pengetahuan saja, maka pada kurikulum 2013 penilaian yang dilakukan harus mencakup tiga aspek sikap, keterampilan, dan pengetahuan.

Sejak diterapkannya kurikulum 2013 pada tahun pelajaran 2017/2018 di SDN 12 Bengkulu Tengah, hasil belajar siswa masih rendah. Hal ini dapat dilihat dari hasil ulangan harian tema 7 (energi dan perubahannya) memperoleh nilai 6,5. Nilai tersebut belum tuntas karena KKM Kelas III SDN 12 Bengkulu Tengah adalah 70. Pembelajaran tematik merupakan pendekatan pembelajaran yang melibatkan 
beberapa mata pelajaran untuk memberi pengalaman yang bermakna bagi anak (Lisa Aida 2018: 8).

Berdasarkan observasi yang dilakukan peneliti terdapat permasalahan dalam proses pembelajaran tematik di kelas III SDN 12 Bengkulu Tengah yaitu: (1) Penilaian pada proses pembelajaran hanya pada aspek konitif/ pengetahuan saja, (2) pembelajaran masih berpusat kepada guru (teaching center), (3) Siswa cenderung ribut dan kurang memperhatikan pembelajaran, (4) Saat melaksanakan diskusi kelompok masih dilakukan secara acak dan jarang memberikan penguatan kepada siswa yang aktif sehingga anak kurang giat untuk lebih semangat dalam belajar.

Salah satu cara yang diambil oleh peneliti untuk meningkatkan pembelajaran tematik yaitu dengan menggunakan model kooperatif think-pair-share (TPS). Model kooperatif tipe TPS yaitu Think (berpikir), Pair (berpasangan), Share (berbagi). Guru tidak lagi sebagai satu-satunya sumber pembelajaran (teacher oriented), tetapi siswa dituntut dapat menemukan dan memahami konsep-konsep baru menurut Sahroni (2011) dalam jurnla (Jasdilla, dkk 2017: 99).

\section{Metode}

Penelitian tindakan kelas yang dilakukan adalah jenis penelitian tindakan kelas (Classroom Action Reaserch). Penelitian tindakan kelas adalah jenis penelitian yang dilakukan olehguru didalam kelasnya melalui refleksi diri dengan tujuan untuk memperbaiki kinerja sebagai guru, sehingga hasil belajar siswa meningkat. Penelitian tindakan kelas memiliki empat tahapan, yaitu : (1) merencanakan (perencanaan), (2) melakukan tindakan (pelaksanaan), (3) mengamati atau observasi, (4) refleksi. (Arikunto 2008 : 16).

Subyek penelitian adalah guru dan siswa kelas III SDN 12 Bengkulu Tengah Tahun Pelajaran 2017-2018 dengan jumlah siswa 24 orang siswa yang terdiri dari 12 orang laki-laki dan 12 orang perempuan. Penelitian ini dilaksanakan di kelas III karena berdasarkan data nilai ulangan umum semester 1 diketahui bahwa prestasi belajar siswa kelas III SDN 12 Bengkulu Tengah masih rendah dengan nilai ratarata kelas 6,5.

Variabel Independen (variabel bebas) adalah variabel yang mempengaruhi atau sebab perubahan timbulnya variabel terikat (dpenden). Dalam penelitian ini yang menjadi variabel independennya adalah model kooperatif TPS.

Variabel Dependen (variabel terikat) adalah variabel yang dipengaruhi, akibat dari adanya variabel bebas. Dalam penelitian ini yang menjadi variabel dependen adalah hasil belajar siswa. 
Instrumen penelitian yang digunakan dalam penelitian ini adalah lembar observasi (Lembar observasi aktivitas guru, Lembar observasi siswa, lembar observasi afektif/ sikap, lembar observasi psikomotor/ keterampilan), dan lembar tes tertulis. Teknik Pengumpulan data menggunakan observasi, dokumentasi dan tes hasil.

Indikator keberhasilan hasil belajar dalam pembelajaran model kooperatif Tipe TPS yang di tinjau dari: 1) Tes Kognitif (Nilai LDS dikatakan tuntas apabila $75 \%$ dari semua kelompok memperoleh nilai $\geq 70$ dan meningkat setiap siklus. Dan nilai evaluasi dikatakan tuntas apabila $75 \%$ dari semua siswa memperoleh nilai $\geq 70$.

Indikator keberasilan tindakan ditinjau dari aspek afektif. Nilai aspek afektif/ sikap dikatakan berhasil apabila persentase siswa yang mencapai kriteria baik setiap aspek meningkat pada tiap siklus.

Indikator keberasilan ditinjau dari aspek psikomotor. Nilai aspek psikomotor/ keterampilan dikatakan berhasil apabila persentase siswa yang mencapai kriteria baik setiap aspek meningkat pada tiap siklus.

\section{Hasil}

\section{Deskripsi Hasil Belajar Siklus I, II, dan III}

\section{a. Nilai LKPD Siklus 1}

Nilai rata-rata yang diperoleh setiap mata pelajaran pada siklus I adalah nilai ratarata 66,66 dengan ketuntasan belajar secara klasikal 33,33\%. Hasil belajar siswa yang diukur menggunakan LKPD pada proses pembelajaran siklus I dapat dilihat pada lampiran 24. Nilai rata-rata dan ketuntasan belajar secara klasikal yang diperoleh pada siklus I disajikan pada tabel 1.

Tabel 1 Nilai Hasil LKPD Siklus 1

\begin{tabular}{|l|c|}
\hline \multicolumn{1}{|c|}{ Aspek Penilaian } & Nilai \\
\hline Nilai Rata-rata & 66,66 \\
\hline Ketuntasan Belajar & $33,33 \%$ \\
\hline
\end{tabular}

Berdasarkan data pada tabel 4.7 dapat dikatakan bahwa siklus 1 persentase ketuntasan belajar siswa pada siklus I yang diukur menggunakan LKPD ini belum bisa dikatakan tuntas karena belum mencapai ketuntasan berdasarkan kurikulum yang secara klasikal proses pembelajaran dapat dikatakan berhasil atau tuntas apabila di kelas siswa memperoleh nilai $\geq 7,0$ sebanyak $75 \%$.

b. Nilai LKPD Siklus 2

Nilai rata-rata yang diperoleh pada siklus 2 adalah nilai rata-rata 72,5 dengan ketuntasan belajar secara klasikal 75\%. Hasil belajar siswa yang diukur 
menggunakan LKPD pada proses pembelajaran siklus 2 dapat dilihat pada lampiran 46.Nilai rata-rata dan ketuntasan belajar secara klasikal yang diperoleh pada siklus 2 disajikan pada tabel 2.

Tabel 2 Nilai Hasil LKPD Siklus 2

\begin{tabular}{|c|c|}
\hline Aspek yang diamati & Siklus 2 \\
\hline Nilai Rata-rata & 72,5 \\
\hline Ketuntasan Belajar & $75 \%$ \\
\hline
\end{tabular}

Berdasarkan tabel 2 dapat dikatakan bahwa ketuntasan belajar siswa yang diukur menggunakan LKPD ini bisa dikatakan tuntas bahwa ketuntasan belajar siswa yang diukur menggunakan LKPD ini bisa dikatakan tuntas apabila sudah mencapai ketuntasan berdasarkan kurikulum yang secara klasikal proses pembelajaran dapat dikatakan berhasil atau tuntas apabila di kelas siswa memperoleh nilai $\geq 7,0$ sebanyak 75\% (KKM SDN 12 Bengkulu Tengah).

\section{c. Nilai LKPD Siklus 3}

Nilai rata-rata yang diperoleh pada siklus 3 adalah nilai rata-rata 76,87 dengan ketuntasan belajar secara klasikal 87,5\%. Hasil belajar siswa yang diukur menggunakan LKPD pada proses pembelajaran siklus 3 dapat dilihat pada lampiran 69 Nilai rata-rata dan ketuntasan belajar secara klasikal yang diperoleh pada siklus 3 disajikan pada tabel 3.

Tabel 3 Nilai Hasil LKPD Siklus 3

\begin{tabular}{|l|l|}
\hline Aspek yang diamati & IPA \\
\hline Nilai Rata-rata & 78,87 \\
\hline Ketuntasan Belajar & $87,5 \%$ \\
\hline
\end{tabular}

Berdasarkan tabel 4.9 dapat dikatakan bahwa ketuntasan belajar siswa yang diukur menggunakan LKPD ini bisa dikatakan tuntas diukur menggunakan LKPD tersebut sudah mencapai ketuntasan berdasarkan kurikulum yang secara klasikal proses pembelajaran dapat dikatakan berhasil atau tuntas apabila di kelas siswa memperoleh nilai $\geq 7,0$ sebanyak 75\% (KKM SDN 12 Bengkulu Tengah).

d. Nilai Evaluasi/ Tes Siklus 1

Penilaian tes dilakukan di akhir Pembelajaran yang dilaksakan pada siklus 1 dengan jumlah soal 5 butir berbentuk essay. Data yang diperoleh dari nilai post tes siklus 1 dari 24 siswa nilai rata-rata 71,25 dengan ketuntasan belajar 62,5\%. Hasil analisis data prestasi belajar siswa pada Siklus 1 disajikan dalam Tabel 4 di bawah ini. 
Tabel 4 Nilai Evaluasi Siklus 1

\begin{tabular}{|l|c|}
\hline \multicolumn{1}{|c|}{ Penilaiam } & Nilai \\
\hline Nilai Rata-rata & 71,25 \\
\hline Ketuntasan Belajar & $62,5 \%$ \\
\hline
\end{tabular}

Berdasarkan tabel 4.7 dapat dilihat bahwa ketuntasan belajar siswa di atas menunjukkan bahwa proses pembelajaran pada siklus 1 belum dikatakan belum tuntas karena sesuai dengan yang dikemukakan oleh KKM SDN 12 Bengkulu Tengah bahwa proses pembelajaran dikatakan tuntas apabila di kelas siswa memperoleh nilai $\geq 7,0$ sebanyak $75 \%$.

\section{Refleksi Nilai Evaluasi/Tes Siklus 1}

Data yang diperoleh dari nilai post tes siklus I yang disajikan pada lampiran 25 bahwa pada siklus I dari 24 siswa nilai ratarata kelas III 71,25 dengan ketuntasan belajar 62,5\%. Berdasarkan data tersebut dapat dilihat bahwa ketuntasan belajar siswa di atas menunjukkan bahwa proses pembelajaran pada siklus I belum dikatakan tuntas karena sesuai dengan yang dikemukakan oleh KKM SDN 12 Bengkulu Tengah bahwa proses pembelajaran dikatakan tuntas apabila di kelas siswa memperoleh nilai $\geq 7,0$ sebanyak $75 \%$.

\section{e. Nilai Evaluasi/Tes Siklus 2}

Penilaian tes dilakukan di akhir Pembelajaran yang dilaksakan pada siklus 2 dengan jumlah soal 5 butir berbentuk essay. Data yang diperoleh dari nilai post tes siklus 2 yang disajikan pada lampiran 47 bahwa pada siklus 2 dari 24 siswa nilai rata-rata 75 dengan ketuntasan belajar $79,16 \%$. Hasil analisis data prestasi belajar siswa pada Siklus 2 disajikan dalam Tabel 5 di bawah ini.

Tabel 5 Nilai Evaluasi Siklus 2

\begin{tabular}{|c|c|}
\hline Aspek yang Diamati & Siklus 2 \\
\hline Nilai Rata-rata & 75 \\
\hline Ketuntasan belajar & $79,16 \%$ \\
\hline
\end{tabular}

Berdasarkan tabel 4.10 hasil belajar di atas menunjukkan bahwa proses pembelajaran pada siklus 2 sudah tuntas karena sesuai dengan yang dikemukakan oleh KKM SDN 12 Bengkulu Tengah bahwa proses pembelajaran dikatakan tuntas apabila di kelas siswa memperoleh nilai $\geq 7,0$ sebanyak $75 \%$. Data lengkap nilai evaluasi (kognitif) siswa siklus 2 dapat dilihat pada lampiran 47.

\section{Refleksi Nilai Evaluasi/Tes Siklus 2}

Data yang diperoleh dari nilai post tes siklus 2 dari 24 siswa nilai rata-rata kelas III 75 dengan ketuntasan belajar 79,16\%. Berdasarkan data hasil belajar di 
atas menunjukkan bahwa proses pembelajaran pada siklus 2 sudah tuntas karena sesuai dengan yang dikemukakan oleh KKM SDN 12 Bengkulu Tengah bahwa proses pembelajaran dikatakan tuntas apabila di kelas siswa memperoleh nilai $\geq 7,0$ sebanyak $75 \%$.

\section{f. Nilai Evaluasi/Tes Siklus 3}

Penilaian tes dilakukan di akhir Pembelajaran yang dilaksakan pada siklus 3 dengan jumlah soal 5 butir berbentuk essay. Data yang diperoleh dari nilai post tes siklus 3 yang disajikan pada lampiran 70 bahwa pada siklus 3 dari 24 siswa nilai rata-rata 78,33 dengan ketuntasan belajar 83,33\%. Hasil analisis data prestasi belajar siswa pada Siklus 3 disajikan dalam Tabel 6 di bawah ini.

Tabel 6 Nilai Evaluasi Siklus 3

\begin{tabular}{|c|c|}
\hline Aspek yang Diamati & Siklus 3 \\
\hline Nilai Rata-rata & 78,33 \\
\hline Ketuntasan belajar & $83,33 \%$ \\
\hline
\end{tabular}

Berdasarkan tabel 4.12 hasil belajar di atas menunjukkan bahwa proses pembelajaran pada siklus 3 sudah tuntas karena sesuai dengan yang dikemukakan oleh KKM 12 Bengkulu Tengah dan indikator ketuntasan belajar, bahwa proses pembelajaran dikatakan tuntas apabila di kelas siswa memperoleh nilai $\geq 7,0$ sebanyak $75 \%$.

\section{Refleksi Nilai Evaluasi/Tes Siklus 3}

Data yang diperoleh dari nilai post tes siklus 3 dari 24 siswa nilai rata-rata kelas III 78,33 dengan ketuntasan belajar 83,33\%. Berdasarkan data hasil belajar di atas menunjukkan bahwa proses pembelajaran pada siklus 3 sudah tuntas karena sesuai dengan yang dikemukakan oleh KKM SDN 12 Bengkulu Tengah bahwa proses pembelajaran dikatakan tuntas apabila di kelas siswa memperoleh nilai $\geq 7,0$ sebanyak $75 \%$.

\section{g. Nilai Ranah Afektif / Sikap Siklus 1}

Tabel 7. Nilai Rata-rata Lembar Penilaian Afektif Siswa Siklus 1

\begin{tabular}{|c|l|c|c|c|c|c|}
\hline \multirow{2}{*}{ No } & \multirow{2}{*}{ Aspek } & \multirow{2}{*}{$\begin{array}{c}\text { Jumlah } \\
\text { Tiap } \\
\end{array}$} & & \multirow{2}{*}{\begin{tabular}{c} 
Rata- \\
rata \\
\cline { 5 - 7 }
\end{tabular}} & Kriteria & \multicolumn{3}{|c|}{ Persentase (\%) } \\
\hline 1 & Menerima & 54 & 2,2 & 4,1 & 66,7 & 29,1 \\
\hline 2 & Merespon & 49 & 2,0 & 12,5 & 70,9 & 16,7 \\
\hline 3 & Menghargai & 47 & 1,9 & 8,3 & 87,5 & 4,1 \\
\hline 4 & $\begin{array}{l}\text { Mengorganis } \\
\text { asikan }\end{array}$ & 61 & 2,5 & - & 45,9 & 54,1 \\
\hline 5 & $\begin{array}{l}\text { Karakteristik } \\
\text { Menurut Nilai }\end{array}$ & 51 & 2,1 & 16,7 & 54,1 & 29,1 \\
\hline
\end{tabular}

Berdasarkan tabel 7 dapat diketahui bahwa kriteria pada lembar observasi afektif siswa selama proses pembelajaran pada siklus I masih menunjukkan kategori cukup dapat dilihat pada persentase masih berada pada kriteria cukup. 
Penerapan Pembelajaran Tematik Melalui Model Kooperatif Think Pair Share (TPS) Untuk Meningkatkan Hasil Belajar Siswa Kelas III SDN 12 Bengkulu Tengah

h. Nilai Ranah Afektif/Sikap Siklus 2

Tabel 8 Kriteria Penilaian Lembar Penilaian Afektif/Sikap Siswa Siklus 2

\begin{tabular}{|c|c|c|c|c|c|c|}
\hline \multirow[b]{2}{*}{ No } & \multirow[b]{2}{*}{ Aspek } & \multirow{2}{*}{$\begin{array}{c}\text { Jumlah } \\
\text { Tiap } \\
\text { Kriteria }\end{array}$} & \multirow{2}{*}{$\begin{array}{c}\text { Rata- } \\
\text { rata } \\
\text { Tiap } \\
\text { Kriteria }\end{array}$} & \multicolumn{3}{|c|}{ Persentase (\%) } \\
\hline & & & & $\mathbf{K}$ & C & B \\
\hline 1 & Menerima & 61 & 2,5 & - & 45,9 & 54,1 \\
\hline 2 & Merespon & 60 & 2,5 & - & 41,7 & 58,3 \\
\hline 3 & Menghargai & 61 & 2,5 & - & 45,9 & 54,1 \\
\hline 4 & $\begin{array}{l}\text { Mengorganisasi } \\
\text { kan }\end{array}$ & 63 & 2,6 & - & 37,5 & 62,5 \\
\hline 5 & $\begin{array}{l}\text { Karakteristik } \\
\text { Menurut Nilai }\end{array}$ & 58 & 2,4 & - & 33,3 & 66,7 \\
\hline
\end{tabular}

Berdasarkan tabel 8. dapat dikatakan bahwa kriteria pada lembar observasi afektif siswa selama proses pembelajaran pada siklus 2 telah berada dalam persentase baik.

\section{i. Nilai Ranah Afektif/Sikap Siklus 3}

Tabel 9 Kriteria Penilaian Lembar Penilaian Afektif/Sikap Siswa Siklus 3

\begin{tabular}{|c|c|c|c|c|c|c|}
\hline \multirow[b]{2}{*}{ No. } & \multirow[b]{2}{*}{ Aspek } & \multirow{2}{*}{$\begin{array}{l}\text { Jumalah } \\
\text { Tiap } \\
\text { Kriteria }\end{array}$} & \multirow{2}{*}{$\begin{array}{c}\text { Rata- } \\
\text { rata } \\
\text { Tiap } \\
\text { Kriteria }\end{array}$} & \multicolumn{3}{|c|}{ Persentase (\%) } \\
\hline & & & & $\mathbf{K}$ & C & B \\
\hline 1 & Menerima & 67 & 2,8 & - & 20,9 & 79,1 \\
\hline 2 & Merespon & 65 & 2,7 & - & 29,1 & 70,9 \\
\hline 3 & Menghargai & 63 & 2,6 & - & 37,5 & 62,5 \\
\hline 4 & $\begin{array}{l}\text { Mengorgan } \\
\text { isasikan }\end{array}$ & 65 & 2,7 & - & 29,1 & 70,9 \\
\hline 5 & $\begin{array}{l}\text { Karakteristi } \\
\text { k Menurut } \\
\text { Nilai }\end{array}$ & 66 & 2,7 & - & 25 & 75 \\
\hline
\end{tabular}

Berdasarkan tabel 9 dapat dikatakan bahwa kriteria pada lembar observasi afektif siswa selama proses pembelajaran pada siklus 2 sudah berada pada persentase baik.

\section{j. Nilai Ranah Psikomotor/Keterampilan Siklus 1}

Tabel 7 Kriteria Penilaian Tiap Aspek Lembar Psikomotor Siswa Siklus 1

\begin{tabular}{|c|l|c|c|c|c|c|}
\hline \multirow{2}{*}{ No } & \multirow{2}{*}{ Aspek } & \multirow{2}{*}{$\begin{array}{c}\text { Jumlah } \\
\text { Tiap } \\
\end{array}$} & & \multirow{2}{*}{$\begin{array}{c}\text { Rata- } \\
\text { rata }\end{array}$} & \multicolumn{3}{|c|}{ Persentase (\%) } \\
\cline { 5 - 7 } & & Kriteria & Kriteria & K & C & B \\
\hline 1 & Meniru & 51 & 2,1 & 8,2 & 70,9 & 20,9 \\
\hline 2 & Memanipulasi & 48 & 2 & 16,7 & 76,1 & 16,1 \\
\hline 3 & Artikulasi & 56 & 2,3 & 4,1 & 62,5 & 33,4 \\
\hline 4 & Presis & 24 & 2,2 & 4,1 & 66,7 & 29,2 \\
\hline
\end{tabular}

Berdasarkan tabel 7. dapat diketahui bahwa kriteria pada lembar observasi psikomotor/ keterampilan siswa selama proses pembelajaran pada siklus I masih menunjukkan persentase cukup.

k. Nilai Ranah Psikomotor/Keterampilan Siklus 2 
Tabel 11 Kriteria Penilaian Tiap Aspek Lembar Psikomotor/ Keterampilan Siswa Siklus 2

\begin{tabular}{|c|l|c|c|c|c|c|}
\hline \multirow{2}{*}{ No } & \multirow{2}{*}{ Aspek } & \multirow{2}{*}{$\begin{array}{c}\text { Jumlah } \\
\text { Tiap }\end{array}$} & \multirow{2}{*}{$\begin{array}{c}\text { Rata- } \\
\text { rata }\end{array}$} & \multicolumn{3}{|c|}{ Persentase (\%) } \\
\cline { 5 - 7 } & & Kriteria & Kriteria & K & C & B \\
\hline 1 & Meniru & 62 & 2,6 & - & 41,7 & 58,3 \\
\hline 2 & Memanipulasi & 61 & 2,5 & - & 45,9 & 54,1 \\
\hline 3 & Artikulasi & 63 & 2,6 & - & 37,5 & 62,5 \\
\hline 4 & Presis & 61 & 2,5 & - & 45,9 & 54,1 \\
\hline
\end{tabular}

Berdasarkan tabel 11 dapat diketahui bahwa kriteria pada lembar penilaian psikomotor/ keterampilan siswa selama proses pembelajaran pada siklus 2 sudah berada pada persentase baik

\section{i. Nilai Ranah Psikomotor/Keterampilan Siklus 3}

Tabel 12. Kriteria Penilaian Tiap Aspek Lembar Psikomotor/ Keterampilan Siswa Siklus 3

\begin{tabular}{|c|c|c|c|c|c|c|}
\hline \multirow{2}{*}{ No } & \multirow{2}{*}{ Aspek } & \multirow{2}{*}{$\begin{array}{c}\text { Jumlah } \\
\text { Tiap } \\
\text { Kriteria }\end{array}$} & \multirow{2}{*}{$\begin{array}{c}\text { Rata- } \\
\text { rata } \\
\text { Kriteri } \\
\text { a }\end{array}$} & \multicolumn{3}{|c|}{ Persentase $(\%)$} \\
\hline & & & & K & $\mathrm{C}$ & B \\
\hline 1 & Meniru & 64 & 2,7 & - & 33,3 & 66,7 \\
\hline 2 & Memanipulasi & 63 & 2,6 & - & 37,5 & 62,5 \\
\hline 3 & Artikulasi & 64 & 2,7 & - & 33,3 & 66,7 \\
\hline 4 & Presis & 62 & 2,5 & - & 41,7 & 58,3 \\
\hline
\end{tabular}

Berdasarkan tabel 12 dapat diketahui bahwa nilai rata-rata pada lembar penilaian psikomotor/keterampilan siswa selama proses pembelajaran pada siklus 3 telah berada pada persentase baik.

\section{Pembahasan}

Teori Bloom (Sudjana, 2009:22) menyatakan bahwa hasil belajar dalam rangka studi, dicapai melalui tiga kategori ranah yakni ranah kognitif (berkenaan dengan hasil belajar intelektual yang terdiri dari 6 aspek yaitu pengetahuan, pemahaman, penerapan, analisis, sintesis dan penilaian), ranah afektif/sikap (berkenaan dengan sikap dan nilai). Ranah afektif/sikap meliputi lima jenjang kemampuan yaitu menerima, merespon, menghargai, mengorganisasikan dan karakterisasi dengan suatu nilai atau kompleks nilai), dan ranah psikomotor/keterampilan (meliputi keterampilan motorik, manipulasi bendabenda, dan menghubungkan konsep). Ranah psikomotor/keterampilan meliputi empat jenjang kemampuan yaitu meniru, memanipulasi, artikulasi, dan presis.

a. Lembar Kerja Peserta Didik (LKPD)

Berdasarkan hasil penilaian LKPD pada siklus I dari jumlah kelompok pada siklus I sebanyak 12 kelompok dengan nilai rata-rata 66,66 dengan ketuntasan 
belajar 33,33\%. Hal ini menandakan bahwa proses kerja kelompok belum berjalan dengan baik masih berada dalam kriteria cukup.

Pada siklus 2 jumlah kelompok sebanyak 12 kelompok. Semua kelompok mengikuti kegiatan kerja kelompok dan dapat dikatakan tuntas dengan nilai ratarata 72,29 dengan ketuntasan belajar 70,83\%. Pada siklus 3 jumlah kelompok 12 . Semua kelompok mengikuti kegiatan erja kelompok dan dapat dikatakan tuntas dengan nilai ratarata 76,87 dengan ketuntasan belajar 87,5\%. Hal ini menandakan bahwa LKPD dapat membantu siswa dalam kegiatan belajar mengajar. Siswa sudah mampu bekerja sama dan memecahkan masalah yang ada dalam LKPD berkaitan dengan materi yang diberikan.

Selain itu, hal di atas juga diperkuat dengan dalam LKPD siswa akan mendapatkan uraian materi, tugas, dan latihan yang berkaitan dengan materi yang diberikan.

\section{b. Nilai Evaluasi}

Berdasakan Hasil penelitian tindakan kelas yang sudah dilaksanakan dalam tiga siklus terjadi peningkatan hasil belajar (kognitif) pada pembelajaran Tematik di kelas III SDN 12 Bengkulu Tengah melalui penerapan model kooperatif TPS. Peningkatan hasil belajar ini berhubungan dengan peningkatan kualitas proses pembelajaran yang ditinjau dari aktivitas guru dan siswa (afektif, psikomotor) selama proses pembelajaran berlangsung.

Peningkatan hasil belajar ini ditunjukkan dengan peningkatan nilai ratarata dan persentase ketuntasan belajar siswa secara klasikal yaitu pada siklus I diperoleh nilai rata-rata 71,25 dengan ketuntasan belajar 62,5\% dalam kriteria cukup. Mengalami peningkatan pada siklus 2 dengan nilai ratarata 75 dengan ketuntasan belajar 79,16\% dengan ketuntasan belajar dalam kriteria baik. Mengalami peningkatan pada siklus 3 dengan nilai rata-rata 78,33 dengan ketuntasan belajar 83,33\% dalam kriteria baik.

Berdasarkan data diatas dapat dinyatakan bahwa hasil belajar siswa menunjukkan proses pembelajaran pada tiap siklus dan sudah tuntas karena sesuai dengan yang dikemukakan oleh KKM SDN 12 Bengkulu tengah bahwa proses pembelajaran dikatakan tuntas apabila di kelas siswa memperoleh nilai $\geq 7,0$ sebanyak 75\%. Keberhasilan ketuntasan belajar secara klasikal pada tiap siklus dikarenakan guru telah melakukan upaya perbaikan terhadap aspek-aspek yang belum terlaksana dengan baik pada siklus I dan siklus 2 sehingga mempengaruhi kegiatan siswa dalam proses pembelajaran. Pada penelitian tindakan kelas ini kegiatan siswa dipengaruhi oleh kegiatan pembelajaran yang dilakukan guru. 
Kegiatan guru terhadap aspek-aspek pada tahap pembelajaran Tematik dengan menerapkan menerapkan model kooperatif TPS yang perlu dilakukan tindakan perbaikan yang berdampak terhadap kegiatan siswa dan kegiatan guru itu sendiri, sehingga skor ratarata observasi aktivitas siswa dan guru siklus I dapat meningkat pada siklus 2 dan siklus 3 .

Selain itu rendahnya hasil belajar siswa pada siklus I di atas dikarenakan beberapa faktor baik dari siswa maupun guru. Faktor penyebab rendahnya hasil belajar pada siklus I antara lain: (a) guru kurang mampu menggunakan model kooperatif tipe TPS dengan memanfaatkan lingkungan sekolah karena sulit mengontrol siswa ketika diajak belajar berkelompok, dan memerlukan waktu yang cukup lama, (b) guru kurang memahami karakteristik siswa, (c) minat siswa dalam mengikuti pembelajaran dengan model kooperatif tipe TPS dengan memanfaatkan lingkungan sekolah masih rendah, (d) banyak siswa yang main-main ketika membentuk kelompok dan pada saat melaksanakan kerja kelompok.

Pada siklus 2 dan siklus 3 hasil belajar siswa sudah dikatakan tuntas. Berdasarkan hasil observasi terhadap aktivitas siswa, ketuntasan yang diharapkan pada siklus I berdampak pada siklus 2 dan siklus 3 sehingga terjadinya peningkatan skor observasi terhadap aktivitas siswa. Peningkatan aktivitas siswa pada siklus 2 dan siklus 3 ini ditunjukkan dengan keterlibatan aktif siswa selama proses pembelajaran berlangsung yang meliputi kegiatan siswa saat melakukan kerja kelompok dengan LKPD, sikap dan keterampilan siswa saat melakukan kerja kelompok dan terciptanya hubungan kerja sama yang baik ketika melakukan kerja kelompok.

\section{c. Nilai Afektif/Sikap}

Berdasarkan hasil pengamatan yang dilakukan oleh guru selama proses pembelajaran Tematik melalui model kooperatif TPS diperoleh gambaran bahwa aktivitas afektif/sikap siswa meningkat disetiap siklusnya. Hal ini ditunjukkan dengan meningkatnya persentase secara klasikal siswa di setiap siklusnya. Perolehan persentase afektif/sikap siswa pada siklus 1 masih berada pada kategori cukup dengan interval nilai tiap kriteria (1,7-2,3), meningkat pada siklus 2 dengan persentasi afektif/ sikap sudah baik dengan interval nilai tiap kriteria (2,4-3) dan meningkat kembali pada siklus 3 dengan persentase afektif/ sikap berada pada kategori baik dengan interval kriteria tiap aspek kriteria (2,4-3).

Peningkatan tersebut tidak lepas dari perbaiakan ditiap proses pembelajaran yang dilakukan dalam upaya meningkatkan afektif/ sikap siswa menjadi lebih baik. Sejalan dengan pendapat Bloom (Sudjana, 2006: 29) ranah afektif menentukan keberhasilan belajar seseorang. 
Peningkatan aktivitas afektif/sikap siswa dalam pembelajaran Tematik melalui model kooperatif TPS ditunjukkan dengan perubahan sikap dan nilai pada siswa.

\section{d. Nilai Psikomotor/Keterampilan}

Berdasarkan hasil pengamatan yang dilakukan oleh guru selama proses pembelajaran Tematik melalui model kooperatif TPS diperoleh gambaran bahwa aktivitas psikomotor/ketermpilan siswa meningkat disetiap siklusnya. Hal ini dapat dilihat dari meningkatnya perolehan skor secara klasikal siswa di setiap siklusnya. Perolehan persentase psikomotor/ keterampilan siswa pada siklus I berada pada kriteria cukup dalam rentang interval tiap aspek (1,7-2,3), meningkat pada siklus 2 dengan persentase baik dalam rentang interval tiap aspek (2,4-3) , meningkat kembali pada siklus 3 dengan persentase baik dalam rentang interval tiap aspek (2,4-3).

Berdasarkan uraian diatas dapat disimpulkan bahwa pembelajaran Tematik dengan menerapkan model pembelajaran 12 kooperatif TPS pada penelitian ini dapat meningkatkan hasil belajar (dari segi ranah afektif/sikap, psikomotor/keterampilan, dan kognitif/pengetahuan) siswa, sehingga penelitian ini dapat diakhiri.

Pada penelitian yang sudah dilakukan, peneliti masih menggunakan langkahlangkah pembelajaran model kooperatif TPS dari Winarni pada tahun 2012. Sedangkan pada tahun 2018 telah dilakukan penelitian oleh Winarni bahwa langkah-langkah pembelajaran model kooperatif TPS sebelumnya masih terdapat kelemahan. Hal tersebut dialami oleh peneliti dimana siswa masih belum percaya diri ketika mereka berbagi hasil secara klasikal, sehingga siswa masih ragu ketika menyampaikan hasil kerja kelompoknya di depan kelas. Dalam bukunya yang berjudul Pendekatan Ilmiah dalam Pembelajaran Kreatif dan Inovatif Winarni menjelaskan langkah-langakah pembelajaran model kooperatif TPS yang sudah dilakukan penelitian pengembangan sebagai berikut :

(1) Tahap 1 Thinking (berpikir)

Guru mengajukan pertanyan atau isu yang berhubungan dengan pelajaran, kemudian siswa diminta untuk memikirkan pertanyaan atau isu tersebut secara mandiri beberapa saat.

(2) Tahap 2 pairing (berpasangan)

Guru meminta siswa berpasangan dengan siswa lain untuk dapat mendiskusikan apa yang telah dipikirkannya pada tahap pertama interaksi pada tahap ini diharapkan dapat berbagi jawaban jika telah diajukan suatu pertanyaan atau berbagi ide jika suatu persoalan khusus telah diidentifikasi. Biasanya guru memberikan waktu 4 samapi 5 menit untuk berpasangan. 
(3) Tahap 3 sharing (berbagi)

Pada tahap ini, guru meminta pasangan siswa untuk membentuk kelompok yang lebih besar yaitu 4 orang atau dua pasangan untuk berbagi tentang apa yang telah mereka pelajari dan seterusnya disampaikan kepada seluruh kelas.

Dengan adanya revisi yang telah dilakukan melalui penelitian pada langkahlangkah pembelajaran model kooperatif TPS tersebut, diharapkan dapat memperbaiki rasa percaya diri siswa dan semua siswa diberikan kesempatan untuk berpartisipasi dalam kelas, sehingga pembelajaran menjadi lebih bermakna.

\section{Kesimpulan}

Berdasarkan hasil penelitian dan pembahasan, maka dapat ditarik kesimpulan sebagai berikut:

a. Nilai Ranah Afektif/ sikap hasil belajar ranah afektif/sikap siswa yang mengalami peningkatan pada siklus I nilai rata-rata 11,68 dengan kriteria cukup, meningkat pada siklus 2 dengan nilai rata-rata 12,08 dengan kriteria baik, dan meningkat kembali pada siklus 3 dengan nilai ratarata 13,98 dengan kriteria baik.

b. Nilai Ranah Psikomotor/keterampilan, hasil belajar ranah psikomotor/keterampilan siswa pada siklus I dengan nilai rata-rata 8,75 dengan kriteria cukup. Meningkat pada siklus 2 dengan nilai rata-rata menjadi 10 dengan kriteria baik, dan meningkat kembali pada siklus 3 dengan nilai ratarata 10,58 dengan kriteria baik.

c. Nilai Lembar Kerja Peserta Didik, nilai diskusi kelompok dilihat dari hasil pengerjaan LKPD dari 12 kelompok, yang mengalami peningkatan nilai ratarata tiap siklus I nilai rata-rata 66,66 dengan ketuntasan belajar 33,33\%, meningkat siklus 2 dengan nilai ratarata 72,29 dengan ketuntasan belajar 70,83\%, dan meningkat lagi pada siklus 3 dengan nilai rata-rata 76,87 dengan ketuntasan belajar $87,5 \%$.

d. Nilai Evaluasi/tes, nilai evaluasi/tes dilihat dari hasil yang diperoleh dari 24 siswa pada siklus I mendapat nilai ratarata 71,25 dengan ketuntasan belajar $62,5 \%$, meningkat pada siklus 2 dengan nilai rata-rata 75 dengan ketuntasan hasil belajara $79,16 \%$, dan meningkat kembali pada siklus 3 dengan nilai ratarata 78,33 dengan ketuntasan belajar 83,33. 


\section{Referensi}

Arikunto, Suharsimi. 2007. Penelitian Tindakan Kelas. Jakarta: Bumi Aksara.

Kadir, Hanun Asrohah. 2014. Pembelajaran Tematik. Jakarta. PT Rajagrafindo Persada.

Murfiah. 2017. Pembelajaran Terpadu Teori dan Praktik Terbaik Di Sekolah. Bandung. Refika Aditama.

Rusman. 2010. Model-model Pembelajaran Mengembangkan Profesional Guru. Jakarta. PT Rajagrafindo Persada 